\title{
Repair and Servicing of Road Vehicles
}

\author{
Lecturer's Guide
}

$$
\text { Part } 1
$$




\title{
Macmillan Motor Vehicle Craft Studies Series
}

\section{LECTURER'S GUIDE}

\section{Repair and Servicing of Road Vehicles}

\section{Part 1}

\author{
Editor Roy Brooks \\ Formerly Senior Lecturer in Motor Vehicle Subjects \\ Bolton Institute of Higher Education \\ Authors Jack Hirst \\ Lecturer in Motor Vehicle Subjects \\ Burnley College \\ John Whipp \\ Senior Lecturer in Motor Vehicle Subjects \\ North Manchester College
}


(C) R. Brooks, J. Hirst and J. Whipp 1989

All rights reserved. No reproduction, copy or transmission of this publication may be made without written permission.

Copyright permission is hereby given to permit lecturers and teachers to make overhead projector transparencies from this publication, solely for their own classroom use.

No paragraph of this publication may otherwise be reproduced, copied or transmitted save with written permission or in accordance with the provisions of the Copyright Act 1956 (as amended), or under the terms of any licence permitting limited copying issued by the Copyright Licensing Agency, 33-4 Alfred Place, London WC1E 7DP.

Any person who does any unauthorised act in relation to this publication may be liable to criminal prosecution and civil claims for damages.

First published 1989

Published by

MACMILLAN EDUCATION LTD

Houndmills, Basingstoke, Hampshire RG21 2XS

$$
\text { and London }
$$

Companies and representatives

throughout the world

ISBN 978-0-333-51013-1

DOI 10.1007/978-1-349-11098-8

SBN 978-1-349-11098-8 (eBook) 


\section{Contents}

Preface

Acknowledgements

UNIT 1.01: VEHICLE SYSTEMS SKILLS

01.01 Road Vehicle Systems and Layouts 2

01.02 Scheduled Servicing 61

01.03 Assembly and Dismantling $\quad 87$

UNIT 1.02: PERSONAL SAFETY 96

02.04 Observing Safe Practices $\quad 97$

02.05 Moving Loads 109

UNIT 1.03: PLANNING SKILLS 112

03.06 Measurement and Dimensional Control 113

03.07 Interpreting Drawings, Specification and Data 126

UNIT 1.04: MANUAL SKILLS 143

04.08 Bench Fitting 144

$\begin{array}{ll}04.09 \text { Joining } & 175\end{array}$

UNIT 1.05: INDUSTRIAL STUDIES 192

$\begin{array}{ll}05.10 \text { Industrial Studies } & 193\end{array}$

UNIT 1.06: VEHICLE SCIENCE

$\begin{array}{ll}06.11 \text { Vehicle Science } & 214\end{array}$

Section 12: BASIC WORKSHOP AND VEHICLE CALCULATIONS 271

Section 13: GLOSSARY OF TECHNICAL TERMS AND ABBREVIATIONS 279 


\section{Preface}

The Lecturer's Guide is intended to be used in conjunction with class sets of Repair and Servicing of Road Vehicles, Part 1, edited by Roy Brooks.

The purpose of this Guide is to provide a model of the way in which the books might be filled in by students. It must be emphasised that there is no definitive way in which the workbooks should be completed, and lecturers may want to depart from the plan outlined here. Some of the blanks have not been filled in because the model answers will vary according to the student's chosen specialism.

Limited copyright clearance has been granted to allow lecturers to produce overhead projector transparencies using this Lecturer's Guide as a master copy (see page iv). Such transparencies can be used as a valuable aid to presentation of lessons.

To obtain the greatest effect when making overhead projector transparencies of incomplete drawings, a transparency from a Student Book should be made and this then overlayed onto the same drawing in the Lecturer's Guide and completed, by tracing, using coloured projector pens. This is a small classwork preparation that conscientious lecturers will find very rewarding.

Any queries relating to this book or to copyright permission for this material should be addressed to the Publisher, Macmillan Education Ltd, Houndmills, Basingstoke RG21 2XS. 


\section{Acknowledgements}

The editor, authors and publishers would like to thank all who helped so generously with information, assistance, illustrations and inspiration. In particular the book's principal illustrator, Harvey Dearden (previously principal lecturer in Motor Vehicle Subjects, Moston College of Further Eduction); colleagues of the Burnley College and the North Manchester College; and the persons, firms and organisations listed below. Should there be any ommissions, they are completely unintentional.

A-C Delco Division of General Motors Ltd. Austin Rover Group Ltd.

Autodata Ltd.

Automobile Association

Automotive Products plc

Avon Rubber Co. Ltd.

BBA Group plc

Robert Bosch Ltd.

R. Boughton Esq.

British Standards Institution

Castrol UK Ltd.

CAV Ltd.

Champion Sparking Plug Co. Ltd.

Citroën UK Ltd.

City \& Guilds of London Institute

Clayton Dewandre Ltd.

Dunlop (SP Tyres UK Ltd.)

Fiat Auto (UK) Ltd.

Firestone UK Ltd.

Ford Motor Co. Ltd.

Girling Ltd.

Hepworth \& Grandage Ltd.

HMSO

Holset Engineering Co. Ltd.

Honda UK Ltd.
T.F. Keller \& Sons Ltd.

Land Rover Ltd.

Lotus Group of Companies

Lucas Industries plc

Luminetion Ltd.

MAN-Volkswagen

Metalistic Ltd.

Mitsubishi Motors

Mobelec Ltd.

Mobil Oil Co. Ltd.

Peugeot Talbot Motor Co. Ltd.

Pirelli Ltd.

Renault UK Ltd.

Ripaults Ltd.

Sherrat Ltd.

Sykes Pichavant Ltd.

Telehoist Ltd.

Unipart Group of Companies

VAG (United Kingdom) Ltd.

Vauxhall Motor Co. Ltd.

Weber Concessionaires Ltd.

Westinghouse CVB Ltd.

Zenith Carburettor Co. Ltd. 